\title{
ALGORITMA MEMBANGKITKAN PROSES POISSON MAJEMUK DENGAN KOMPONEN PROSES POISSON NONHOMOGEN FUNGSI LINEAR DAN KOMPONEN BERDISTRIBUSI EKSPONENSIAL
}

\author{
Syarif Abdullah ${ }^{1 *}$, Sidik Susilo ${ }^{1}$, Shofiatul Ula ${ }^{1}$, Aswata $^{1}$, Nina Valentika ${ }^{2,3}$, Sri Istiyarti \\ Uswatun Chasanah $^{4}$ \\ ${ }^{1}$ Program Studi Teknik Mesin, Sultan Ageng Tirtayasa \\ ${ }^{2}$ Program Studi Matematika, Universitas Pamulang \\ ${ }^{3}$ Program Studi Matematika, Universitas Islam Negeri Syarif Hidayatullah \\ ${ }^{4}$ Program Studi Matematika, Universitas Islam Negeri Sunan Kalijaga \\ *Corresponding Author Email: abdullahsyarifayis@gmail.com
}

\begin{abstract}
The compound Poisson process is one of the developments of a stochastic process. This process is a model to illustrate a real phenomenon that occurs which has an element of uncertainty. This process has two main components, namely the frequency component that has the Poisson process, and the severity component which has the i.i.d (independent and identically distributed) distribution. This research discusses the making of an algorithm to generate compound Poisson processes with nonhomogeneous Poisson process components in the form of linear functions and exponentially distributed components. The method used is the acceptance-rejections method with the thinning process technique. The results of the research have obtained the algorithm to generate compound Poisson processes and their simulations. These algorithms can be used for computational analysis simulations in various fields of science.
\end{abstract}

Keywords: Algorithm, exponential distribution, linear function.

\begin{abstract}
ABSTRAK
Proses Poisson majemuk merupakan salah satu pengembangan dari salah satu proses stokastik. Proses ini merupakan suatu model untuk mengilustrasikan suatu fenomena nyata yang terjadi yangmana memiliki unsur ketidakpastian. Proses ini memiliki dua komponen utama, yaitu komponen frekuensi yang memiliki proses Poisson, dan komponen seferitas yang memiliki distribusi i.i.d (independent and identically distributed). Penelitian ini membahas tentang pembuatan algiritma untuk membangkitkan proses Poisson majemuk dengan komponen proses poisson nonhomogen berupa fungsi linear dan komponen berdistribusi eksponensial. Metode yang digunakan adalah dengan metode acceptancerejections dengan teknik thinning process. Hasil penelitian telah didapatkan algoritma membangkitkan proses Poisson majemuk beserta simulasinya. Algoritma-algoritma tersebut dapat digunakan untuk simulasi analisis komputasi pada berbagai bidang ilmu.
\end{abstract}

Kata kunci: algoritma, distribusi eksponensial, fungsi linear.

\section{PENDAHULUAN}

Dalam fenomena nyata terdapat banyak sekali peristiwa-peristiwa yang mengandung usur kejadian acak. Belum tentu kejadian yang telah terjadi pada masa lampau akan berulang terjadi pada masa sekarang dan akan datang. Namun bisa jadi kejadian tersebut akan berulang kembali, seperti kejadian siklik atau periodik. Sehingga dari fenomena-fenomena nyata 
tersebut dibuatlah suatu model yang dapat menyerupai dengan model yang sebenarnya. Model yang sesuai selanjutnya diharapkan dapat memprediksi kejadian yang akan datang baik dari segi keutungan atau segi kerugian. Dalam ilmu statistik probabilitas, apabila suatu fenomena nyata tersebut mengandung unsur ketidakpastian dan mengandung aturan peluang, maka peristiwa tersebut tergolong pada suatu peristiwa proses stokastik.

Dilihat dari waktu, proses stokastik dapat dibedakan menjadi proses stokastik diskrit dan proses stokastik kontinu. Salah satu proses stokastik kontinu yang sering digunakan untuk menghitung banyakya kejadian yang terjadi, baik keberhasilan atau kegagalan pada waktu tertentu atau interval waktu tertentu, yaitu proses Poisson. Menurut fungsi intensitasnya, Proses ini dibedakan menjadi proses Poisson homogen (homogeneous Poisson process (HPP)) dan proses Poisson nonhomogen (nonhomogeneous Poisson process (NHPP)). HPP memiliki fungsi intensitas yang diasumsikan memiliki fungsi intensitas waktu konsan (tidak bergantung pada waktu), sedangkan NHPP memiliki fungsi intensitas yang tidak konstan (bergantung pada waktu). Salah satu contoh HPP dan NHPP dalam bidang teknik dapat dilihat dalam Pahlajani et al. (2014), Cha (2013) dan Soltanali et al. (2019).

Pemodelan proses stokastik yang tidak hanya menghitung banyakya kejadian yang muncul pada interval waktu tertentu, namun juga menghitung akibat atau efek dari kejadian itu terjadi disebut dengan proses majemuk. Proses majemuk terdiri dari minimal 2 komponen, yaitu komponen banyaknya kejadian (frequency) dan komponen besaran akibat (severity). Dalam hal ini, komponen sebaran frequency yang dimaksud adalah sebaran banyaknya kejadian pada suatu periode tertentu dan komponen sebaran severity adalah sebaran besar akibat yang ditimbulkan ketika kejadian itu terjadi, dapat berupa besaran uang atau yang lain. Apabila diasumsikan pada komponen frekuensi berupa proses Poisson, maka proses majemuk tersebut dinamakan proses Poisson majemuk (compound Poisson process (CPP)). Sedangkan pada komponen frekuensi dapat diasumsikan berupa sebaran ekspoensial, gamma, pareto dan lain-lain yang sesuai dengan besaran akibat dari kejadian.

Model CPP dengan asumsi pada komponen frekuensinya memiliki komponen HPP, dimana HPP diasumsikan memilki fungsi intensitas konstan, memiliki banyak aplikasi pada berbagai bidang, misalnya pada bidang biologi, seismografi, demografi, asuransi dan keuangan (lihat referensi pada Abdullah et al. (2017) dan bidang teknik (Andrzejczak et al. (2018)). Namun, apabila dalam suatu kejadian yang terjadi memiliki kejadian yang naik atau turun pada suau periode tertentu, dimana memiliki fungsi intensitas yang tidak lagi konstan 
(bergantung pada waktu), maka model tersebut tidak sesuai. Sehingga perlu dikembangkan model baru dimana komponen frekuensi pada CPP diasumsikan memiliki bentuk NHPP. Selajutnya, apabila dalam suatu kejadian yang terjadi memilki kejadian yang cenderung berulang sehingga memiliki sifat siklik atau periodik, maka model tersebut harus diubah dengan bentuk NHPP dengan fungsi intensitas berbentuk fungsi periodik (Ruhiyat et al. (2013), Mangku et al. (2013) dan Makhmudah et al. (2016)). Karena fungsi intensitas ini memiliki fungsi yang berulang pada periode selanjutnya, maka model ini bagus untuk mendeskripsikan fenomena yang terjadi periodik. Lebih lanjut, apabila dalam model memiliki sifat yang tidak hanya memiliki sifat periodik, namun memiliki sifat periodik yang memiliki tren linear, maka model tersebut harus diubah dengan bentuk NHPP dengan fungsi intensitas berbentuk fungsi periodik dengan tren linear (Wibowo et al. (2017) dan Abdullah et. al (2017)).

Algoritma untuk melakukan simulasi pada model CPP dengan komponen frekuensi berupa NHPP dan asumsi pada bagian komponen severity berupa distribusi eksponesial belum dibuat. Sehingga pada penelitian ini bertujuan untuk membuat algoritma untuk membangkitkan suatu bilangan acak pada model proses Poisson majemuk (compound Poisson process (CPP)) dengan komponen proses poisson nonhomogen (nonhomogeneous Poisson process (NHPP)) berupa fungsi linear dan komponen berdistribusi eksponensial (exponential distribution (ED)). Hasil dari algoritma ini dapat digunakan dalam analisis model pada simulasi komputasi, misalnya untuk analisis reabilitas, total kerugian (aggregate loss) dan ukuran risiko, misalnya: value of risk (VaR) dan expected shortfall (ES), dalam teori risiko. Sehingga perusahaan dapat memberikan proteksi atau perlindungan terhadap kemungkinan kejadian dimasa akan datang yang dapat menimbulkan kerugian finansial.

\section{METODOLOGI}

Kerangka pikir penelitian ini didasarkan pada penelitian lanjutan untuk menyelesaikan open problems yang belum terpecahkan yang diillustrasikan pada Gambar 1. Sesuai dengan tujuan penelitian diawal, maka penelitian dilanjutkan dengan topik bahasan dengan mengasumsikan komponen pada komponen frekuensi berupa proses Poisson nonhomogen yang memiliki fungsi intensitas berupa fungsi linear dan komponen akibat (severity) berupa variabel acak dari distribusi eksponensial. Warna hitam pada Gambar 1 mengillustrasikan tentang penelitian telah dilakukan oleh beberapa peneliti sebelumnya, warna merah 
mengillustrasikan tentang open problems, sedangkan warna biru mengillustrasikan tentang hasil pada penelitian ini.

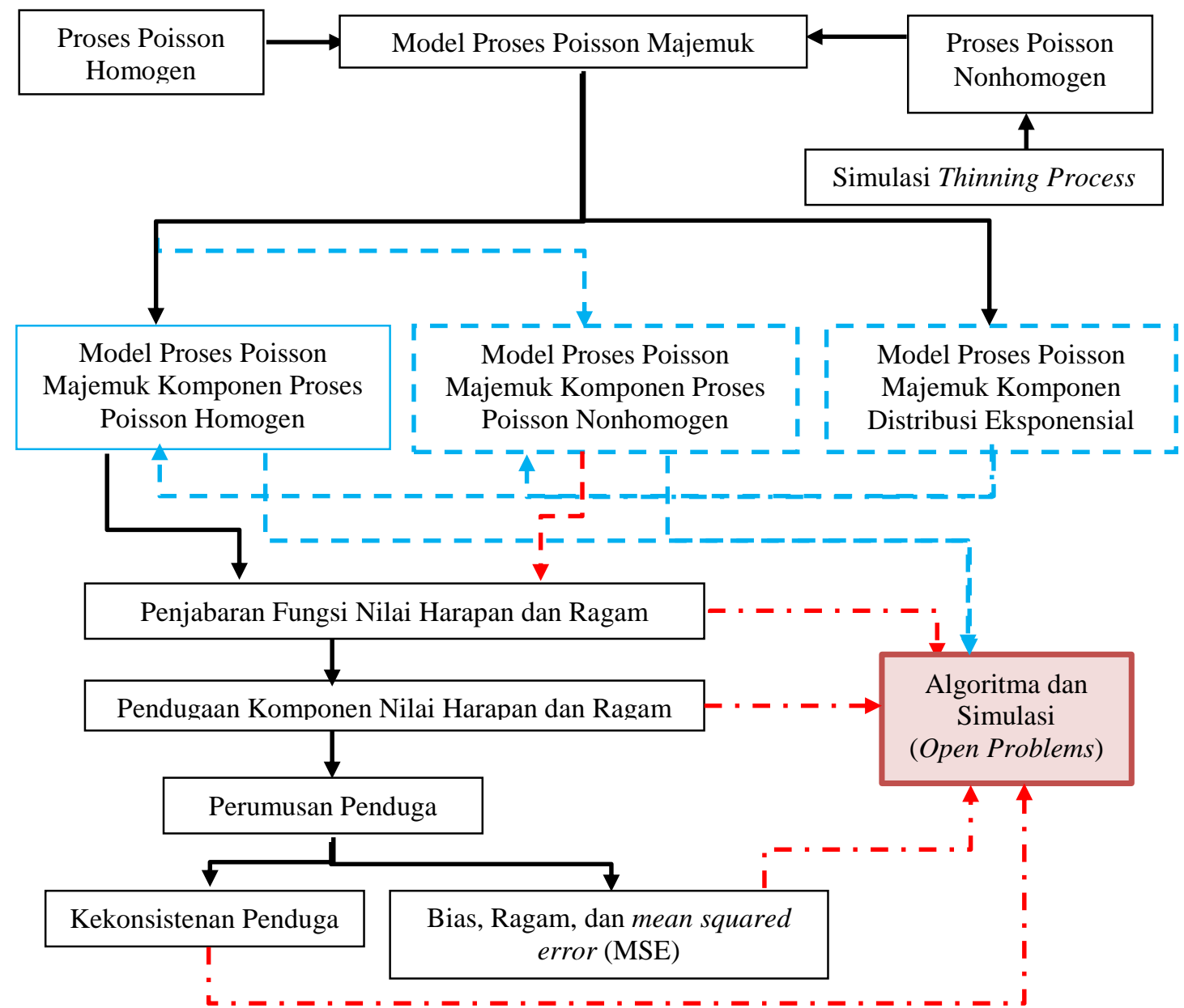

$$
\begin{array}{lll}
\text { Keterangan: } & \rightarrow & : \text { Penelitian Sebelumnya } \\
& -. \rightarrow & : \text { Open Problems } \\
& -\rightarrow & : \text { Hasil penelitian }
\end{array}
$$

Gambar 1. Kerangka Pikir Penelitian

Simulasi pada proses Poisson nonhomogen (nonhomogeneous Poisson process (NHPP)) yang digunakan adalah metode simulasi komputasi acceptance-rejections dengan teknik thinning process. Teknik thinning process ini pertama kali dikenalkan oleh Lewis dan Shedler (1979) dan dikembangkan oleh Ross (2010). Modifikasi algoritma yang digunakan pada penelitian ini adalah modifikasi pada Abdullah (2019), yaitu algoritma pembangkitan pada proses Poisson majemuk. Adapun langkah-langkah yang dilakukan dalam penelitian diillustrasikan pada Gambar 2. 


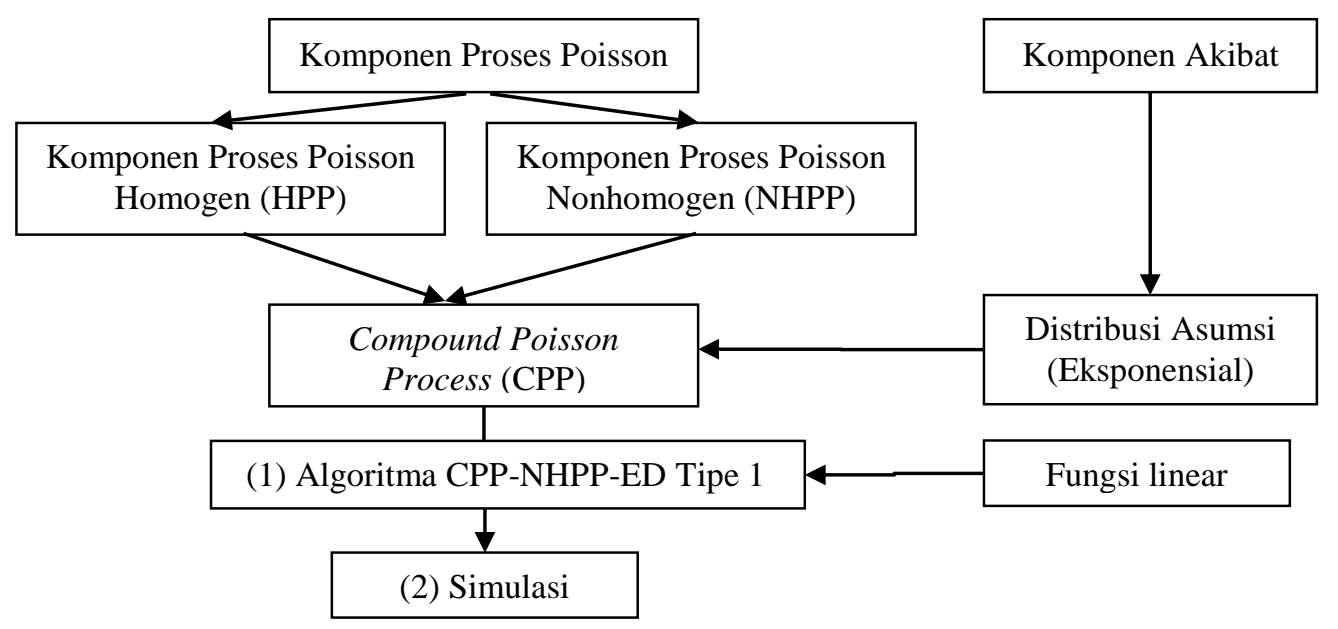

Gambar 2. Langkah Penelitian

Sehingga langkah-langkahnya yaitu:

1. Membuat algoritma untuk membangkitkan CPP yang memiliki komponen NHPP fungsi linear dan berdistribusi eksponensial.

2. Membuat simulasi algoritma sesuai tujuan penelitian.

\section{HASIL DAN PEMBAHASAN}

Pada bagian ini dibahas tentang proses Poisson majemuk dengan komponen NHPP fungsi linear dan distribusi eksponensial dan algoritma untuk membangkitkan proses tersebut.

\subsection{Proses Poisson Majemuk dengan Komponen NHPP Fungsi Linear dan Distribusi} Eksponensial.

\subsubsection{Proses Poisson Majemuk dengan Komponen HPP dan Distribusi Eksponensial.}

Proses pencacahan $\{\mathrm{N}(\mathrm{t}), t \geq 0\}$ merepresentasikan banyaknya kejadian yang terjadi pada waktu $T$. Proses ini dikatakan sebagai proses Poisson homogen (HPP) jika memiliki disrtibusi Poisson dan memiliki fungsi intensitas $\lambda>0$. Karena memiliki memiliki fungsi intensitas yang konstan, maka dikatakan proses ini tidak bergantung pada waktu. Definisi formal dan teorema HPP dapat dilihat pada Ross (2010). Nilai harapan dan varian dari HPP berturut-turut sebagai berikut:

$$
E[N(t)]=\lambda t \text { dan } \operatorname{var}[N(t)]=\lambda t .
$$

Proses Poisson majemuk memiliki 2 komponen utama, yaitu komponen banyaknya kejadian yang diasumsikan memiliki proses Poisson dan komponen besaran akibat. Definisi proses Poisson majemuk sebagai berikut: 


\section{Definisi 1:}

Suatu proses $\{\mathrm{Y}(\mathrm{t}), t \geq 0\}$ dikatakan sebagai satu proses Poisson majemuk jika proses tersebut dapat direpresentasikan sebagai,

$$
\mathrm{Y}(\mathrm{t})=\sum_{i=1}^{\mathrm{N}(\mathrm{t})} X_{i}, t \geq 0,
$$

dengan $\{\mathrm{N}(\mathrm{t}), t \geq 0\}$ adalah suatu proses Poisson, dan $\left\{X_{i}, i \geq 1\right\}$ adalah suatu keluarga dari variabel acak yang independent and identically distributed (i.i.d) yang juga bebas dari $\{\mathrm{N}(\mathrm{t}), t \geq 0\}$ (Ross (2012)).

Proses Poisson majemuk dengan komponen frekuensinya berupa proses Poisson dengan fungsi intensitas konstan memiliki nilai harapan (dinotasikan $\left.\psi_{1}(t)\right)$ dan varian (diotasikan $\left.V_{1}(t)\right)$ berturut-turut sebagai berikut (Ross (2012)):

$$
\begin{gathered}
\psi_{1}(t)=E[Y(t)]=E[N(t)] E\left[X_{1}\right] \\
V_{1}(t)=\operatorname{var}[Y(t)]=E[N(t)] E\left[X_{1}^{2}\right] .
\end{gathered}
$$

Asumsikan bahwa $X_{i}$ berdistribusi eksponensial dengan parameter $\theta$, maka nilai harapan, varian dan orde ke- $2 X_{i}$ berturut-turut sebagai berikut:

$$
E\left[X_{1}\right]=\frac{1}{\theta}, \operatorname{var}\left[X_{1}\right]=\frac{1}{\theta^{2}} \text { dan } E\left[X_{1}^{2}\right]=\frac{1}{\theta^{2}} .
$$

Dengan mensubstitusikan persamaan (1) dan (5) ke persamaan (3) dan (4), maka didapatkan berturut-turut,

$$
\begin{gathered}
\psi_{1}(t)=\frac{\lambda t}{\theta}, \text { dan } \\
V_{1}(t)=\frac{\lambda t}{\theta^{2}}
\end{gathered}
$$

\subsubsection{Proses Poisson Majemuk dengan Komponen NHPP Fungsi Linear dan Distribusi Eksponensial.}

Proses pencacahan $\left\{\mathrm{N}(\mathrm{t})^{*}, t \geq 0\right\}$ dikatakan sebagai proses Poisson nonhomogen (NHPP) jika memiliki disrtibusi Poisson dan memiliki fungsi intensitas tak kostan $\lambda(t)>0$. Karena memiliki memiliki fungsi intensitas yang tidak konstan, maka dikatakan proses ini bergantung pada waktu. Definisi formal dan teorema NHPP dapat dilihat pada Ross (2010). Nilai harapan dan varian dari HPP berturut-turut sebagai berikut: 


$$
E\left[N^{*}(t)\right]=\Lambda(t)=\operatorname{var}\left[N^{*}(t)\right]
$$

Dengan $\Lambda(t)=\int_{0}^{t} \lambda(s) d s$.

Proses Poisson majemuk dengan komponen frekuensinya berupa proses Poisson dengan fungsi intensitas tak konstan (dinotasikan $Y^{*}(t)$ ) memiliki nilai harapan (dinotasikan $\psi_{2}(t)$ ) dan varian (dinotasikan $V_{2}(t)$ ) berturut-turut sebagai berikut (Utami (2018) dan Abdullah (2017)):

$$
\begin{gathered}
\psi_{2}(t)=E\left[Y^{*}(t)\right]=E\left[N^{*}(t)\right] E\left[X_{1}\right] \\
V_{2}(t)=\operatorname{var}\left[Y^{*}(t)\right]=E\left[N^{*}(t)\right] E\left[X_{1}^{2}\right] .
\end{gathered}
$$

Dengan mensubstitusikan persamaan (8) dan (5) ke persamaan (9) dan (10), maka didapatkan berturut-turut,

$$
\begin{gathered}
\psi_{2}(t)=\frac{\Lambda(t)}{\theta}, \text { dan } \\
V_{2}(t)=\frac{\Lambda(t)}{\theta^{2}} .
\end{gathered}
$$

Asumsikan bahwa NHPP memiliki fungsi intensitas berupa fungsi linear, sehingga didapatkan,

$$
\lambda(s)=a+b s \text { dan } \Lambda(t)=\int_{0}^{t} \lambda(s) d s=a t+\frac{b}{2} t^{2} .
$$

Dengan mensubstitusikan persamaan (13) ke persamaan (11) dan (12), maka didapatkan:

$$
\begin{gathered}
\psi_{2}(t)=\frac{a}{\theta} t+\frac{b}{2 \theta} t^{2}, \text { dan } \\
V_{2}(t)=\frac{a}{\theta^{2}} t+\frac{b}{2 \theta^{2}} t^{2} .
\end{gathered}
$$

\subsection{Algoritma Proses Poisson Majemuk dengan Komponen NHPP Fungsi Linear dan Distribusi Eksponensial.}

Algoritma membangkitkan proses Poisson majemuk dengan komponen NHPP fungsi linear dan distribusi eksponensial (CPP-NHPP-ED) memiliki 3 langkah utama, yaitu:

1. Membangkitkan suatu proses NHPP (dinotasikan $Z_{i}$ ) yang memiliki intensitas fungsi linear.

2. Membangkitkan suatu bilangan acak $X_{i}$ yang memiliki distribusi eksponensial (ED). 
3. Menghitung CPP.

Sesuai dengan definisi NHPP dan Definisi 1 (persamaan (2)), misalkan proses $N(t)$ terdefinisi pada ruang $\Omega$, sehingga untuk setiap $\omega \in \Omega$ terdefinisi pada ruang peluang $(\Omega, F, P)$. Proses ini memiliki fungsi intensitas tak linear $\lambda(t)$ dan diobservasi. Fungsi $N(\omega)$ merupakan suatu realisasi tunggal dari banyaknya kejadian yag terjadi pada interval $(0, t]$ dengan $N(0)=0$. Misalkan bahwa untuk setiap titik data yang diobservasi pada $N(\omega)$ berkorespondensi dengan suatu keluarga variabel acak i.i.d $X_{i}$ berdistribusi eksponensial dengan parameter $\theta\left(X_{i} \sim \exp (\theta)\right)$.

Modifikasi pada algoritma Abdullah (2019) dilakukan dengan mengganti proses NHPP berupa fungsi linear dan distribusi eksponensial. Ingat bahwa untuk membangkitkan NHPP, harus dipilih nilai $\lambda$ sehingga $\lambda(t) \leq \lambda$ untuk semua $t \leq T$ dan dengan nilai peluang $\lambda(t) / \lambda$. Setiap $Z_{i}$ diobservasi, maka $Z_{i}$ menghasilkan realisasi tunggal untuk memulai membangkitkan $X_{i}$ dan diberikan nilai dengan distribusi eksponensial. Berikut adalah modifikasi algoritma untuk membangkitkan CPP-HPP-ED yang diillustrasikan pada flowchart Gambar 3.
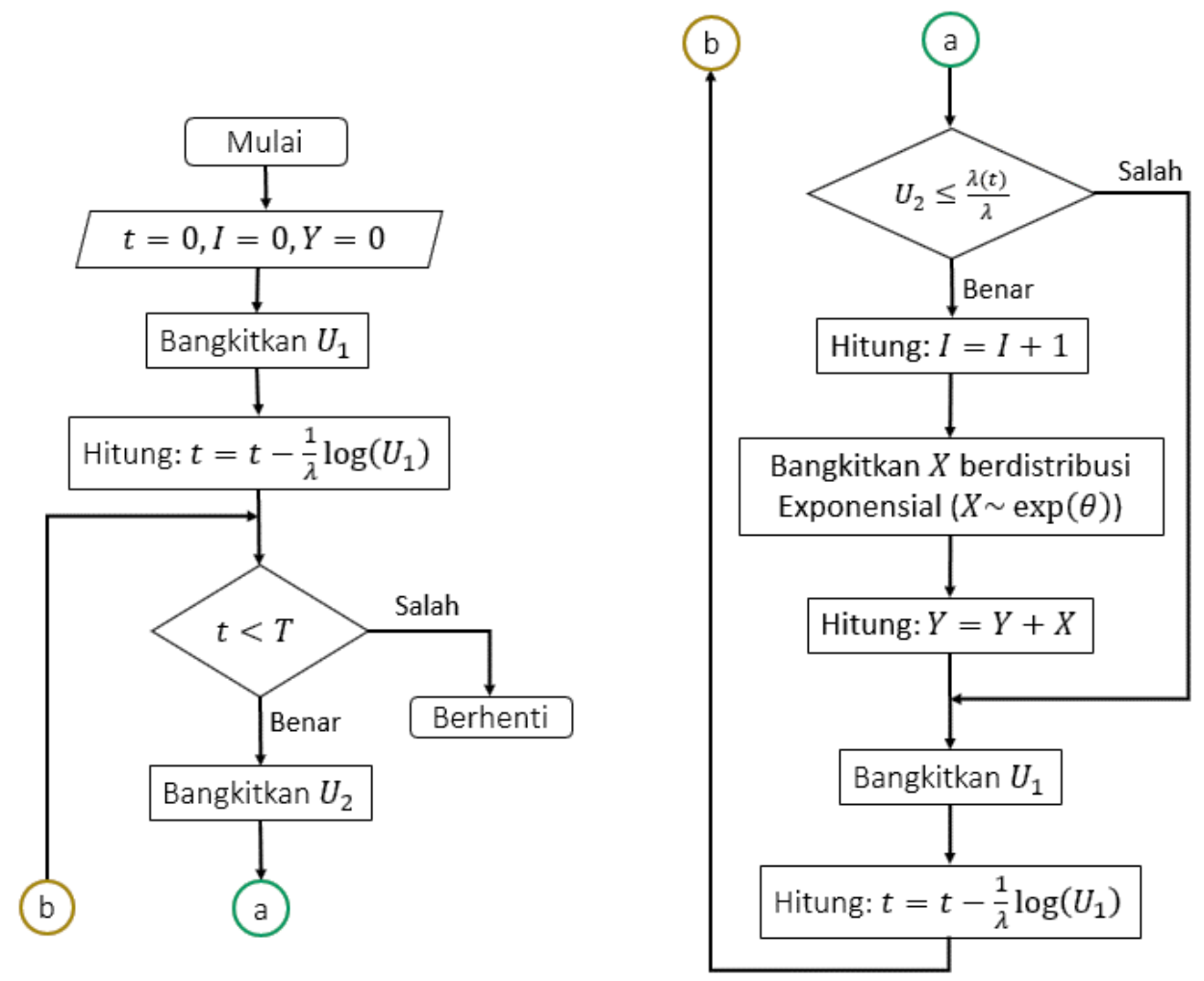

Gambar 3. Flowchart CPP-NHPP-ED. 


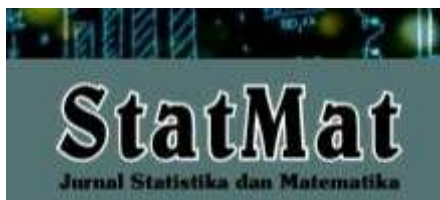

P-ISSN: 2655-3724

STATMAT (Jurnal Statistik dan Matematika), Vol. 2, No. 1, 2020

Halaman: 81-93

@Prodi S-1 Matematika FMIPA Unpam

Berikut adalah langkah-langkah modifikasi pembutan algoritma CPP-NHPP-ED.

Langkah $1: t=0, I=0, Y^{*}=0$.

Langkah 2 : Bangkitkan $U_{1}$.

Langkah $3 \quad$ : Hitung $t=t-\frac{1}{\lambda} \log \left(U_{1}\right)$.

Langkah $4 \quad$ : Jika $t>T$, Berhenti.

Langkah 5 : Bangkitkan $U_{2}$.

Langkah $6 \quad$ : Jika $U_{2} \leq \lambda(t) / \lambda$.

Langkah $7 \quad$ : Hitung $I=I+1$.

Langkah $8 \quad$ : Bangkitkan $X(X \sim \exp (\theta)$.

Langkah $9 \quad$ : Hitung $Y^{*}=Y^{*}+X$.

Langkah 10 : Ulangi langkah 2.

Arti dari simbol-simbol pada flowchart dan algoritma di atas berturut-turut adalah sebagai berikut: $t$ merepresentasikan waktu, $I$ merepresentasikan banyaknya kejadian yang terjadi pada waktu $t, Y^{*}$ merepresentasikan CPP-NHPP-ED, $U_{1}$ dan $U_{2}$ merepresentasikan bilangan acak berdistribusi seragam, $\lambda(t)$ merepresentasikan fungsi intensitas tak konstan berupa fungsi linear $\lambda(t)=a+b t$ dengan $\lambda(t) \leq \lambda, T$ merepresentasikan unit waktu pertama dan $X$ merepresentasikan sebagai bilangan acak berdistribusi eksponensial dengan parameter $\theta$.

\subsection{Simulasi}

Pada bagian ini dibahas tentang simulasi dari algoritma yang telah dibahas pada bagian sebelumnya. Pertama dibahas tentang simulasi NHPP yang dibandingan dengan HPP. Kemudian dilakukan simulasi untuk CPP yang memiliki komponen HPP dan NHPP fungsi linear dan berdistribusi eksponensial.

Simulasi dilakukan dengan mengambil beberapa fungsi intensitas sebagai berikut:

1. $\lambda_{1}(t)=2$

2. $\quad \lambda_{2}(t)=\frac{1}{15} t$

3. $\lambda_{3}(t)=1+\frac{29}{30} t$

Asumsi dengan mengambil waktu $0 \leq t \leq 20=T$ dan $X_{i}$ memiliki distribusi 
eksponensial dengan parameter $\theta=2$. Pembaca dapat mengganti fungsi intensitas dan menetapkan asumsi lain yang diinginkan.

\subsubsection{Simulasi Proses Poisson Nonhomogen}

Sesuai dengan definsi HPP, maka dengan fungsi intensitas pada persamaan (16) didapatkan nilai harapan dan varian pada HPP berturut-turut sebagai berikut:

$$
E\left[N_{1}(t)\right]=\operatorname{var}\left[N_{1}(t)\right]=2 t .
$$

Sedangkan dengan definsi NHPP, maka dengan fungsi intensitas pada persamaan (17) dan (18) didapatkan nilai harapan dan varian pada NHPP berturut-turut sebagai berikut:

$$
\begin{gathered}
E\left[N_{2}(t)\right]=\operatorname{var}\left[N_{2}(t)\right]=\frac{1}{30} t^{2} \\
E\left[N_{3}(t)\right]=\operatorname{var}\left[N_{3}(t)\right]=t+\frac{29}{60} t^{2}
\end{gathered}
$$

Dengan menggunakan teknik thinning process dan melakukan banyak perulangan sebanyak 10.000 kali pada fungsi intensitas pada persamaan (16-18) maka didapatkan titik kejadian dan banyak kejadian yang terjadi yang diillustrasikan pada Gambar 4.

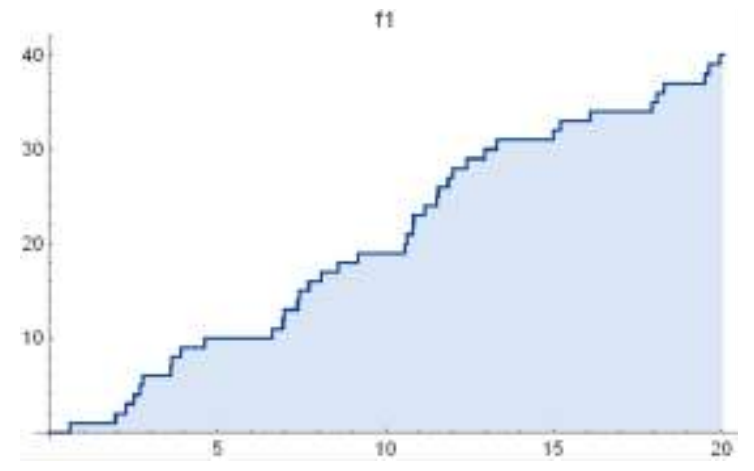

(a)

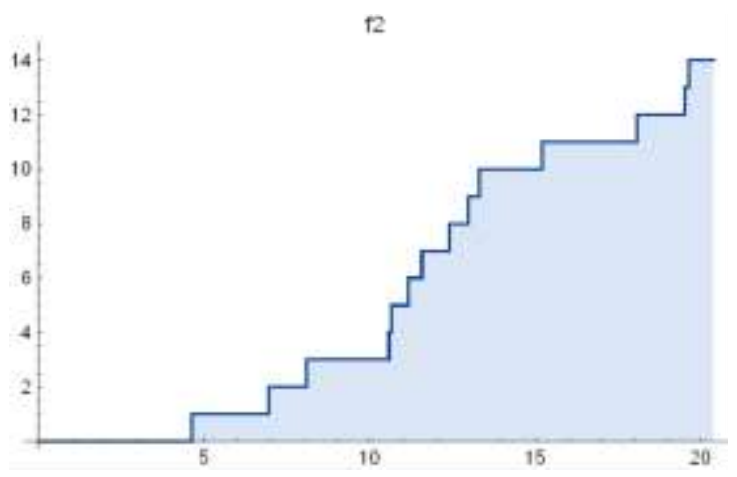

(b)

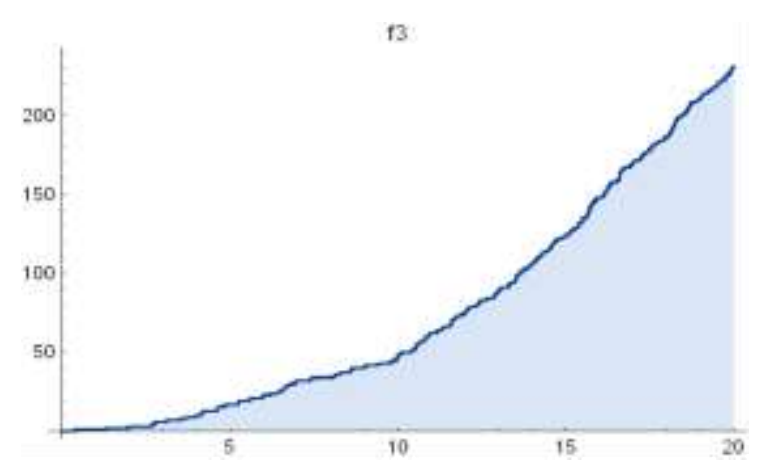

(c)

Gambar 4. Titik kejadian dan banyak kejadian: (a) HPP pada persamaan (16), (b)

NHPP pada persamaan (17) dan (c) HPP pada persamaan (18) 
Gambar 4a terlihat bahwa banyak kejadian pada fungsi intensitas persamaan (16) memiliki banyak kejadian yang lebih banyak dibandingkan dengan fungsi intensitas pada persamaan (17), namun lebih sedikit dibandingkan fungsi intensitas pada persamaan (18). Gambar 4b terlihat bahwa pada fungsi intensitas persamaan (17) memiliki banyak kejadian yang lebih sedikit dibandinngkan dengan fungsi intensitas pada persamaan (16) dan (18). Sedangkan pada Gambar 4c, yang memiliki fungsi intensitas persamaan (18) memiliki banyak kejadian yang paling banyak dibandingkan dengan fungsi intensitas pada persamaan (16) dan (17). Hal ini sesuai dengan teori pada persamaan (1) dan (8).

\subsubsection{Simulasi Proses Poisson Majemuk}

Asumsikan CPP dengan mengambil waktu $0 \leq t \leq 20, X_{i}$ memiliki distribusi eksponensial dengan parameter $\theta=2$ dan perulangan sebanyak 10.000 kali pada fungsi intensitas pada persamaan (16-18). Dengan menggunakan algoritma yang telah dibahas pada bagian sebelumnya, maka didapatkan CPP-HPP-ED dan CPP-NHPP-ED intenitas fungsi linear yang diillustrasikan pada Gambar 5.

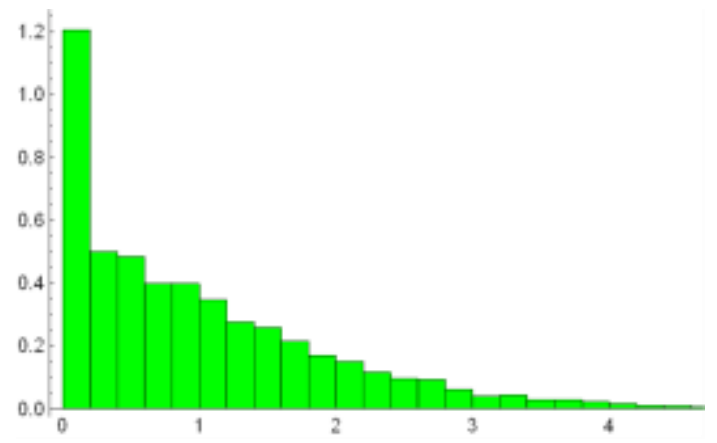

(a)

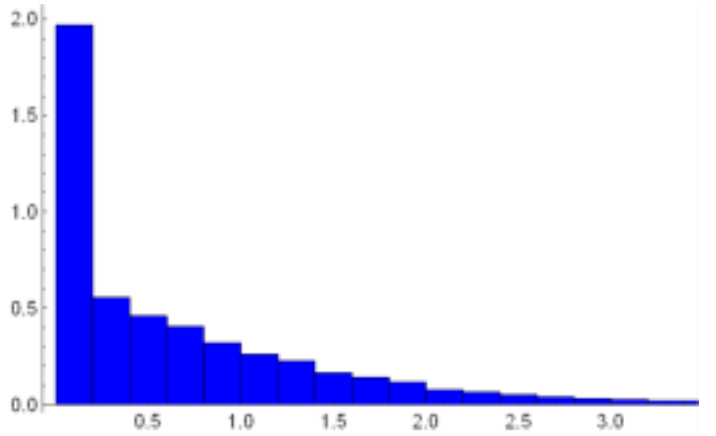

(b)

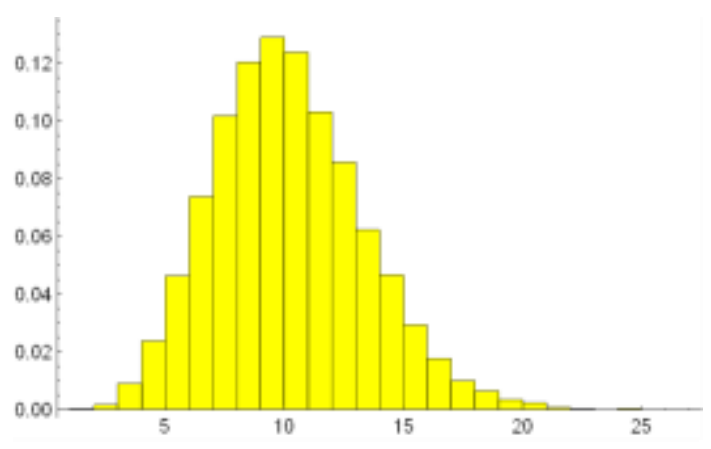

(c)

Gambar 5. CPP: (a) CPP-HPP-ED pada persamaan (16), (b) CPP-NHPP-ED pada persamaan (17) dan (c) CPP-NHPP-ED pada persamaan (18) 
Analisis terhadap hasil simulasi pada Gambar 5c terlihat bahwa CPP-NHPP-ED pada intensitas fungsi linear untuk persaman (18) memiliki agregat yang paling banyak dibandingkan dengan agregat untuk fungsi intensitas pada persaman (16) dan (17). Hal ini terjadi karena dengan fungsi intensitas persamaan (18) memiliki kejadian yang terjadi paling banyak dibandingkan dengan menggunakan fungsi intensitas persamaan (16) dan (17). Hal ini sesuai dengan teori yang dibahas pada bagian sebelumya. Analisis untuk hasil Gambar 5a dan Gambar 5b serupa. Selanjutnya dari hasil ini dapat digunakan untuk analisis model pada simulasi komputasi, misalnya untuk analisis reabilitas, total kerugian (aggregate loss) dan ukuran risiko, misalnya: value of risk (VaR) dan expected shortfall (ES), dalam teori risiko, namun tidak dibahas pada paper ini.

\section{SIMPULAN}

Hasil penelitian telah didapatkan algoritma untuk membangkitkan suatu bilangan acak pada model proses Poisson majemuk (compound Poisson process (CPP)) dengan komponen proses poisson nonhomogen (nonhomogeneous Poisson process (NHPP)) berupa fungsi linear dan komponen berdistribusi eksponensial (exponential distribution (ED)). Hasil dari algoritma ini dapat digunakan dalam analisis model pada simulasi komputasi pada berbagai bidang ilmu.

\section{DAFTAR PUSTAKA}

Abdullah S. 2017. Pendugaan fungsi ragam pada proses Posson periodik majemuk dengan tren linear [tesis]. Bogor (ID): Institut Pertanian Bogor.

Abdullah S, Ikhsan F, Ula S, Rukmayadi R. 2019. Thinning process algorithms for compound Poisson process having nonhomogeneous Poisson process (NHPP) intensity functions. International Conference: Broad Exposure to Science and Technology (BEST) 2019. IOP Conf. Series: Materials Science and Engineering. 673 (2019) 012062. doi: $10.1088 / 1757-899 X / 673 / 1 / 012062$

Abdullah S, Mangku IW, Siswadi. 2017. Estimating the variance function of a compound cyclic Poisson process in the presence of linear trend. Far East Journal of Mathematical Sciences. 102(3):559-572. doi:org/10.17654/MS102030559.

Andrzejczak K, Młyńczak M, Selech J. 2018. Poisson-distributed failures in the predicting of the cost of corrective maintenance. Eksploatacja i Niezawodnosc-Maintenance and 
Reliability. 20(4):602-609. doi:org/10.17531/ein.2018.4.11.

Cha JH. 2013. On a stochastic failure model under random shocks. International Conference on Mathematical Modelling in Physical Sciences IOP Publishing. Journal of Physics: Conference Series. 410 (2013) 012108. doi:10.1088/1742-6596/410/1/012108.

Lewis PAW, Shedler GS. 1979. Simulation Poisson process by thinning. Naval Postgraduate School Montery [Thesis]. California (US).

Makhmudah FI, Mangku IW, Sumarno H. 2016. Estimating the variance function of a compound cyclic Poisson process. Far East Journal of Mathematical Sciences. 100(6):911-922. doi:org/10.17654/MS100060911.

Mangku IW, Ruhiyat, Purnaba IGP. 2013. Statistical properties of an estimator for the mean function of a compound cyclic Poisson process. Far East Journal of Mathematical Sciences. 82(2):227-237.

Pahlajani CD, Poulakakis I, Herbert G, Tanner HG. 2014. Networked decision making for Poisson processes: Application to nuclear detection. IEEE Transaction on Automatic Control. 59(1):193-198. doi:org/10.1109/TAC.2013.2267399.

Ross SM. 2010. Introduction to Probability Models. 9th Ed. Florida (US): Academic Press.

Ross SM. 2012. Simulation. 5th Ed. Amsterdam (NL): Academic Press.

Ruhiyat, Mangku IW, Purnaba IGP. 2013. Consistent estimation of the mean function of a compound cyclic Poisson process. Far East Journal of Mathematical Sciences. 77(2):183-194.

Soltanali H, Rohani A, Tabasizadeh M, Abbaspour-Fard MH, Parida A. 2019. Operational reliability evaluation-based maintenance planning for automotive production line. Quality Technology \& Quantitative Management. Taylor and Francis Group. doi:org/10.1080/16843703.2019.1567664.

Utami S. 2018. Interval kepercayaan fungsi nilai harapan dan fungsi ragam proses Poisson majemuk dengan intensitas eksponensial fungsi linear [tesis]. Bogor (ID): Institut Pertanian Bogor.

Wibowo BA, Mangku IW, Siswadi. 2017. Statistical properties of an estimator for the mean function of a compound cyclic Poisson process in the presence of linear trend. Arab Journal of Mathematical Science. 23(2):173-185. doi:10.1016/j.ajmsc.2016.08.004. 